\title{
İran Dış Politikasında Ontolojik Güvenlik Arayışı ve Filistin Meselesine Yaklaşım
}

\author{
İlknur Cihangir Demirbaş
}

\section{Öz}

İran'ın 1979 devrimiyle birlikte sahip olduğu kimliksel perspektif onun dış politikasının yönünü de yeniden tayin etmiş, zaman içerisinde dış politika adına bir takım esnekliklere sahip olunmuşsa da kimi hususlara olan yaklaşımın özenle korunduğu gözlenmiştir. Geleneksel yaklaşımların öngördüğü biçimde dış politikanın yalnızca fiziki güvenlik ve materyal çıkarlar odağında şekillendiği varsayımından hareket edildiği takdirde, bu kapsamda çeşitli maliyetleri göze almak pahasina da olsa sürdürülen ısrarlı politikaları açıklamak güçtür. İran dış politikasının işleyişinde ontolojik güvenliğin rolünün analiz edildiği bu çalışmada, İran'ın fiziksel güvenlik ve materyal çıkarı kadar ontolojik güvenliğe dair kaygılarının da onun dış politika eylemleri açısından belirleyici olup olmadığı hususunun değerlendirilmesi amaçlanmıştır. Bu doğrultuda, Ontolojik Güvenlik Teorisi (OGT)'nden istifade edilen çalışmada, İran dış politikasında sıkı sıkıya sahiplenilen ve süreklilik arz eden kimi meselelerin ontolojik güvenlik arayışı ile ilişkilendirilebileceği varsayımından hareket edilmiştir. İran'ın Filistin meselesine yaklaşımı üzerinden bir değerlendirme yapılan çalışmada, hegemonya karşıtlığ 1 , müstekbirler karşısında müstazafların önderliği, zulme karşı adalet arayıcılığı gibi öz-anlatılara sahip İran açısından, Filistin meselesine olan yaklaşımın bir "ontolojik güvenlik sağlayıcı rutine" tekabül ettiği, dolayısıyla ontolojik güvenlik hususunun da İran dış politikasının tayininde belirleyici olduğu sonucuna varılmıştır. Bu doğrultuda, ontolojik güvenlik bağlamında değerlendirildiğinde İran'ın öz-imajını muhafaza etme ve öz-anlatılarını sürdürme gayesinin bu meseleye iliş̧in güçlü bir direniş gayreti yarattığı ve buna ilişkin kaygıların eylemleri biçimlendiren bir ontolojik direnç meydana getirdiğini söylemek olanaklıdır.

Anahtar Kelimeler: Ontolojik Güvenlik, Kimlik, İran, İran Dıı̧ Politikası, Filistin Meselesi.

Dr., Bağımsız Araştırmacı, Ankara, Türkiye, ilknurcihangir@gmail.com, ORCID: 0000-0002-3284-8212 


\title{
The Quest for Ontological Security in Iranian Foreign Policy and Iranian Approach to The Palestinian Issue
}

\author{
İlknur Cihangir Demirbaş*
}

\begin{abstract}
The identity perspective that Iran had with the 1979 revolution re-determined the direction of its foreign policy, and it was observed that the approach to some issues was carefully preserved, although some flexibility was achieved in terms of foreign policy over time. It is difficult to explain such persistent policies, which are carried out at the expense of various costs, if it is assumed that foreign policy is shaped only by the focus of physical security and material interests, as predicted by traditional approaches. In this study, which analyzes the role of ontological security in the course of Iranian foreign policy, is aimed to evaluate whether, as well as physical security and interests, ontological security concerns are determinative in terms of its foreign policy actions. In this study, it is assumed that there are ontological security concerns behind some of the ongoing issues that are firmly adopted in Iran's foreign policy. This study, which is handled within the framework of the Ontological Security Theory (OST), has been carried out with a focus on Iran's approach to the Palestinian issue. It has been concluded that the approach to the Palestinian issue corresponds to an "ontological securityproviding routine" for Iran, which has self-narratives such as anti-hegemony, the leadership of the oppressed people, and seeking justice against persecution. When analyzed in the context of ontological security, it is possible to say that Iran's aim of preserving its self-image and maintaining its self-narratives has formed a strong resistance effort regarding this issue, and concerns about this have created an ontological resistance that shapes actions.
\end{abstract}

Keywords: Ontological security, Identity, Iran, Iran Foreign Policy, Palestinian Issue.

PhD., Independent Researcher, Ankara, Turkey, ilknurcihangir@gmail.com, ORCID: 0000-0002-3284-8212 


\section{Giriş}

İran'ın dış politika anlayışı özellikle doksanlı yıllardan başlayarak kimi değişimler geçirmiştir. Bununla birlikte, bazı politikalardaki ısrarın her şeye rağmen sürdürüldüğ̈ gözlenmiştir. İran'ın Filistin meselesine yaklaşımı ve İsrail'e yönelik tutumu da bu duruma birer örnek teşkil etmektedir. İran, devrimden bu yana izlediği siyaset doğrultusunda, gerektiğinde çeşitli manevralar geliştirmek suretiyle Filistin meselesiyle sürekli temasta kalmaya gayret etmiştir. Yeni rejimin hayat bulduğu 1979 senesini takiben İran, İsrail-Filistin arasındaki meselenin hem yakın takipçisi ve hem de farklı biçimlerde eşlikçisi olmaya çabalamıştır. Meseleye ilgisi bulunan devlet dışı aktörlerle yakın teması ise, özellikle Batılı aktörler bazında küresel siyasetteki imajına ve bu doğrultuda ikili ilişkilerine olumsuz tesir etmesine karşın gayretle sürdürülmüştür. Filistin meselesinin çözümü adına kimi taraflarca söz konusu olan farklı girişimleri savuşturulması gereken hamleler biçiminde değerlendiren İran, bu gibi gelişmelere sıklıkla yüksek tondan bir itiraz geliştirmiştir. Kısacası, İran meseleye yaklaşımında "Filistinliden çok Filistinli olmak" (Sadjadpour \& Takeyh, 2005; ayrıca (bknz.) Menashri, 2007, s. 153-167) olarak ifade edilen bir tutumu benimsemiştir.

Bu çalışmada, 'İan dış politikasında çeşitli maliyetleri göze almak pahasına süreklilik arz ettiği görülen ısrarlı politikaların ardında ne gibi faktörlerden söz edilebilir?' sorusuna yanıt aranmakta ve dış politikada bedel ödemek pahasına sıkı sıkıya sahiplenilen kimi politikaların ontolojik güvenliğe ilişkin kaygılar etrafında şekillendiği varsayımından hareket edilmektedir. Bu doğrultuda, İran'ın fiziksel güvenlik ve materyal çıkarı kadar ontolojik güvenliğe dair kaygılarının da onun dış politika eylemleri açısından belirleyiciliğinin bulunup bulunmadığı hususunun değerlendirilmesi çalışmanın temel gayesini oluşturmakta olup söz konusu değerlendirme için İran'ın İsrail'e ve Filistin meselesine olan yaklaşımı esas alınmaktadır. Geleneksel yaklaşımlarca öngörüldüğü biçimde dış politikanın yalnızca fiziksel güvenlik ve materyal çıkarlar ekseninde şekillendiği varsay1mıyla hareket edildiği takdirde, bu gibi hususlarda göze alınan maliyetli tutumları gerekçelendirmek güçtür. Ontolojik güvenliğe ilişkin kaygıların da devletlerin izledikleri dış politikalar adına belirleyici olduğu savını ileri süren OGT ise bu noktada önemli bir açıklayıcılığa sahiptir. Bu sebeple, çalışmanın yürütülmesinde OGT'nin temel savlarından istifade edilmesi uygun görülmüştür. 
Çalışma üç kısımdan meydana gelmektedir. İlk kısımda, öncelikle ontolojik güvenlik kavramına odaklanılmakta ve çalışma açısından dikkat çekici teorik varsayımlara değinilerek ilgili literatür gözden geçirilmektedir. İkinci kısımda, İran'ın 1979 devrimini takiben şekillenen öz-anlatıları ve kendilik nitelendirmelerine ve bunların ontolojik güvenlik algılamalarıyla ilişkisine yer verilmeye gayret edilmektedir. Son kısımda ise, İran'ın Filistin meselesine ilgisi ve İsrail'e yönelik politikaları üzerinde durulmakta ve bu politikalar üzerinde ontolojik güvenliğe ilişkin kaygıların ne gibi bir etkinliği bulunduğu sorusuna yanıt aranarak, seçilmiş olan vaka OGT üzerinden değerlendirilmektedir.

\section{Ontolojik Güvenlik Teorisi}

Devletlerin izlediği politikalar ve bunların ne gibi faktörler dahilinde belirlendiği meselesi bugüne dek pek çok çalışmanın doğrudan ya da dolay11 konusu olmuş, ilgili anlamlandırma çabalarına farklı perspektifler eşlik etmiştir. Geleneksel yaklaşımlar devletlerin politik eylemlerini güç, çıkar ve güvenliğe ilişkin kaygılarla ilişkilendirirken, söz konusu güvenlik olgusunun ise daha ziyade fiziksel güvenliğe göndermede bulunduğu görülmektedir. Ancak, materyal çıkarın ve gücün muhafazası ve mümkün mertebe artırımı temelinde bir güvenlik anlayışından hareket eden bu gibi bir perspektif kimi devlet davranışlarını açıklamakta yetersiz kalabilmektedir. Weldes (1996, s.30)'in de belirttiği gibi, geleneksel yaklaşımlar için, devletler adına tehdit yaratacak hususlar fiziksel güvenliği ifade eder şekilde çoğu zaman bellidir ve söz konusu genelleme kimi farklı hususların niçin devletler adına tehdit algılamaları ortaya çıkardığını açıklamakta güçlük çeker. Ortaya çıkan bu tehdit algılamalarına yönelik devlet eylemlerinin ulusal çıkarla ilişkisini ise açıklayamaz. Ancak son yıllarda, söz konusu boşluğu dolduracak biçimde güvenlik olgusunun kapsamını yeniden değerlendiren çeşitli çalışmalar yürütülmüştür. Güvenlik olgusunun çerçevesinin genişleme evresinde özellikle doksanlı yılları takiben sürdürülen çalışmaların öncüllüğünden söz etmek mümkündür (detaylı bir değerlendirme için bknz. Bilgin, 2010). Bu öncü çalışmaların kendisinden sonra gelen teorik gelişmeler açısından da ilham verici olduğu söylenebilir. $\mathrm{Bu}$ doğrultuda gelişen OGT de Uluslararası İlişkiler (UI) disiplini içerisinde henüz oldukça yakın bir geçmişe sahiptir. 
Ontolojik güvenliğe kavramsal olarak ilk kez Ronald David Laing'in psikanaliz alanındaki çalışmalarında rastlandığı kabul edilmektedir. "Fiziksel doğum ve biyolojik yaşarlılığı [...] gerçek yaşayan olarak varoluşsal [doğuş] izler" diyen Laing (2015, s. 39)'e göre, "sonrasında birey kendi varlığını gerçek, yaşayan ve bütün olarak; [...] dünyanın geri kalanından farklılaşmış olarak; zamanda sürekli bir dizi olarak; içsel bir tutarlılığa, [...] sahip olarak [...] yaşantılayabilir. Böylece o sıkı bir ontolojik güvenlik çekirdeğine sahip olur" (Laing, 2015, s. 39-40). Alışılageldik biçimiyle güvenlik olgusu fiziksel anlamda güvenliğe göndermede bulunurken, ontolojik güvenlik daha ziyade benliğe ilişkin süreklilik arzusunu ve ihtiyacını ifade eden bir güvenlik olgusunu belirtir. Bu bağlamda ontolojik güvenlik, edenlik duygusunun benlik duygusuyla olan paralelliğine dikkat çekerek benlik duygusuna ilişkin sürekliliğin edenlik duygusu adına bir ön koşul olduğunun altını çizer (Kinvall and Mitzen, 2017, s. 4). Yani, İnşacılık(Constructivism)'ın önemli isimlerinden Alexander Wendt (2012, s. 295)'in de vurguladığı gibi, devletler sahip oldukları kimlikleri korumak adına "belli şeyleri yapmak zorunda"dır, bahsi geçen "şeylerin ne olduğunu" bulmak ve bu doğrultuda davranmak ise devletlerin sahip olması gereken özelliklerdendir.

Ontolojik güvenlik olgusunun farklı disiplinlerdeki gelişimine kaynaklık eden bir diğer önemli çalışma ise, Anthony Giddens tarafindan sosyoloji alanında gerçekleştirilmiştir. Giddens(2019)'a göre, ontolojik güvenlik varlığın fiziksel güvenliğinden ziyade, varoluşunu tanımlayan varlığın ne ya da kim olmaya ilişkin kaygılarından ileri gelen bir güvenlik olgusunu belirtmektedir. Ona göre, ontolojik güvenlik “çoğu insanın öz kimliklerinin sürekliliğine ve onları çevreleyen sosyal ve maddi eylem ortamlarının tutarlılığına olan güvenini ifade eder" (Giddens, 1991, s. 92). Laing de benzer biçimde, ontolojik güvenliğin bireyin kendilik kavrayışının belirli bir düzlemde, herhangi bir kırılmaya uğramadan ilerleyebilmesi gayreti ile sağlandığından söz etmektedir. Laing, bireyin olası kimliksel tehditlerden sakınmak adına özsel varlığını kendinden ya da ötekinden kaynaklanabilecek zorlayıcı durumlar karşısında koruyan güçlü bir özerklik hissine gereksinim duyduğunun altını çizmektedir. Ona göre, asli varlığın sonlanması "temel varoluşsal çekirdek" olarak adlandırılabilecek olan 'benlik hissi'nin yitirilmesi durumunu ifade etmektedir. Laing, kimliğin yitirilmesine dair kaygıların fiziksel güvenlik endişelerinden ayrılığını vurgulamakta ve bunun önemine değinmektedir (Laing, 2015, s. 39-48). 
Giddens (2019, s. 107- 109)'a göre, "iç-bütünlüklü bir bireysel-kimli[k]" ancak bir anlatı ile mümkündür. Ona göre, benlik kendiliğinden mevcut bir sabit olarak değerlendirilemez, doğrudan birey etkinliğinin bir ürünüdür ve "bireyin refleksif etkinlikleri içinde rutin bir biçimde yaratılması ve sürdürülmesi gereken bir şeydir". Ona göre, "[b]üyük ölçüde istikrarlı bir bireysel-kimlik duygusuna sahip olan bir kişi, refleksif olarak kavrayabildiği ve farklı ölçülerde diğer insanlara iletebildiği bir "biyografik süreklilik duygusu"na sahiptir ve "[b]ireysel-kimlikle ilgili varoluşsal sorun bireyin kendisi hakkında "sunduğu" biyografinin kırılgan doğasıyla bağlantılıdır. Bir kişinin kimliği ne davranış içinde ne de -önemli olsa bile- diğerlerine tepkide değil, öznel bir anlatıyı sürdürebilme kapasitesinde bulunabilir" (Giddens, 2019, s. 77-80). Bireyin sahip olduğu "biyografinin sürekli olarak dış dünyada ortaya çıkan olaylarla bütünleştirilmesi ve bunların benlik hakkındaki süregelen "hikaye"ye dahil edilmesi gerekir" (Giddens, 2019, s. 80). Laing bu bağlamda kimliğin yitirilmesine dair endişelerden söz eder. Ona göre, "temel varoluş çekirdeği" tehdit altında olduğunda ortaya çıkan “" "benliğin” yitirilmesi endişesi”, fiziksel varlığın sonlanmasından daha fazlasına, "asli varlığın sona erdirilişin[e]" dair duyulan bir kaygıya işaret eder (Laing, 2015, s. 48).

U.İ. disiplini dahilinde gelişen ontolojik güvenlik literatürü, güvenlik olgusunun devlet bazında yalnızca fiziksel güvenliği ifade etmediğinin, öznenin fiziki varlığına yönelik kaygılar dışında özne benliğinin de tehdit altında hissedilebileceğinin altını çizerek, anlatının ve kimliğin sürekliliğini ve bu sürekliliğe ilişkin kaygıları odağına alır. Ontolojik güvenlik kavram1, sunmuş olduğu vizyonla U.İ. disiplininde yeni değerlendirmelere katk1 sağlamış ve kimi çalışmalar öncülüğ̈̈nde U.İ. yazınına katılmıştır. Dolay1sıyla, bu kavram etrafinda şekillenen OGT ile birlikte Uluslararası İlişkiler disiplini dahilinde güvenlik olgusunun kapsamı genişlemiş ve alanda yeni değerlendirmelere kapı aralanmıştır. Bu doğrultuda örneğin Huysmans (1998, s. 239), güvenliğin yalnızca fiziki yok oluşa ilişkin kaygıları ifade etmediğini aynı zamanda belirsizliğin yarattığı endişeyi de ifade ettiğini vurgulamış, gündelik güvenlik (daily security) ve ontolojik güvenlik (ontological security) ayrımından söz ederek disiplinde güvenliğin anlamının yeniden irdelenmesine katkı sağlamıştır. Steele (2008) ise, devletin rasyonelliği ilkesini gözden geçirerek ontolojik güvenliğe ilişkin kaygıların devletleri rasyonel olmayan biçimde davranmaya itebildiğinin altını çizmiştir. Rumelili (bknz. 2015a; 2015b) çalışmasında, ontolojik güvenlik literatü- 
rünün güvenlikleştirme ve çatışma çözümü alanındaki analizler açısından önemli bir katkıya sahip olduğundan söz etmiştir.

OGT, "güvenliğin sadece fiziksel varlık değil aynı zamanda istikrarlı bir benlik gerektirdiği varsayımına dayanarak, Uİ'de devlet ve devlet dışı öznelerin istikrarlı benlik arayışlarını ve bu arayışların siyasi sonuçlarını konu etmiştir" (Rumelili \& Adısönmez, 2020, s. 2). Mitzen (2006a, s. 274), Giddens (2019, s. 95)'nn “bütünlüklü, sürekli ve güvenilir bir dünyada yaşama" ile gelişen bir durum olarak betimlediği "temel güven" düşüncesinden yola çıkarak devletlerin "temel güven sistemi rutinleri[nin] kimliğin sarsılmasına ve kaosa karşı bir tür güvenlik duvarı görevi” gördüğünden söz etmektedir. Giddens (2019, s. 62-63)'a göre, kaosu aşmanın yolunun rutinleri sürdürmekten geçerken, Mitzen (2006a, s. 274), "rutinlerin terkedilmesi, gerçekleşmesi güç bir biçimde edenlik duygusunun feda edilmesi anlamına gelir" demektedir. Mitzen (2006a, s. 272), devletlerin yalnızca fiziksel güvenlik arayışında olmadıklarının yanı sıra kimliksel güvenliklerini sürdürme gayretinde olduklarının altını dikkatle çizer. Ona göre, fiziksel güvenlik kadar ontolojik güvenliğe de ihtiyaç duyan devletler bu gereksinimlerini "devletlerarası rutinler vasitasiyla" temin ederler.

Ontolojik güvenliği "fiziksel bedenin değil, benliğin veya kimliğin güvenliğini ifade eden" bir kavram olarak tanımlayan Mitzen ve Larson (2017, s. 3-4)'a göre, rutinler ve tekrarlanan öz-anlatılar ontolojik güvenliğe katk1 sağlarken, bu husustaki istikrarsızlık fikri ise devletler adına kaygı yaratan bir faktöre işaret etmekte ve bir ontolojik güvensizlik durumuna neden olmaktadır. Onlara göre, “[o]ntolojik güvenlik arayışı, kendimizi olduğumuzu hissettiğimiz kişiyi bize hatırlatan ve yeniden üreten uygulamalara bilinçli olarak katılmak anlamına gelir." Dolayısıyla, OGT devletlerin kimi zaman neden dış politika çıkarlarıyla örtüşmeyen eylemlere yönelebilmekte olduğunu açılamak için de önemli bir araç vazifesi üstlenmektedir (Rumelili \& Adısönmez, 2020, s. 16). Böylelikle, temel olarak ontolojik güvenlik meselesinin de en az fiziksel güvenlik kadar yaşamsal olabildiği ve bu bağlamda devlet eylemleri üzerinde belirleyici bir rol oynayabildiğinden söz edilebilmektedir. Hatta, Steele (2008)'ye göre devletlerin ontolojik güvenliği hem onların kendileri hakkındaki hem de diğerlerinin onlar hakkındaki kanaatlerini onaylayıcı bir role sahip oluşundan ötürü fiziksel güvenlikten bile daha elzemdir. Ona göre, "[u]lus-devletler ontolojik güvenlik ararlar çünkü tutarlı benlik kavrayışlarını sürdürmek isterler ve dev- 
letlerin 'benliği', rutinleştirilmiş diş politika eylemlerine hayat veren bir anlat1 yoluyla oluşturulur ve sürdürülür"' (Steele, 2008, s. 2).

Ontolojik güvenliğe ilişkin literatürde devletlerin dış politikalarında kimliksel güvenlik bağlamında süreklilik arz eden uygulamalardan "ontolojik güvenlik sağlayan rutinler" olarak söz edilmiştir (bknz. Kinnvall \& Mitzen, 2017, s.2). Giddens (2019, s. 171)'a göre, birey yaşamının ““"normal" ve "öngörülebilir"” olması adına rutinlere ihtiyaç vardır. Kinnvall ve Mitzen (2017, s. 2)'e göre, “[a]ktörler, başkaları ile olan ilişkilerinde ve bu ilişkiler yoluyla desteklenen ve tanınan bir biyografik süreklilik ve bütünlük hissine sahip olduklarını hissettiklerinde ontolojik olarak güvenli olarak görülürler." Rumelili ve Adisönmez (2020, s. 3) bu durumu, "[b] irey kendi varlığını devamlılık içinde deneyim etme ihtiyacı duyar. (...) Bireyin dününü, bugününü ve yarınını tutarlı bir şekilde birleştiren bir özanlatıya sahip olması ve bu öz-anlatının diğerleri tarafından kabul görmesi, kendisini aynı kişi olarak deneyim etmesini sağlar" diyerek ifade etmiştir. Ancak, "aktörlerin varoluşsal olarak yaslandığı ilişkiler ve anlayışlar istikrarsız hale geldiğinde, ontolojik güvenlik tehdit altındadır ve sonuç kaygı, felç veya şiddet olabilir" (Kinnvall \& Mitzen, 2017, s. 2). Yani, Giddens (2019, s. 68-69)'ın da belirttiği gibi, bu durum birey adına kaygı ve kaosu tetikleyici bir sonuç ortaya çıkarabilir.

Buraya dek bahsedilenlerden anlaşılacağı üzere ontolojik güvenlik öncelikle insan davranışları özelinde detaylandırılmış bir mefhumdur. U.İ. alanına dahil oluşu ise devlet tutumlarını anlamlandırma çabası gereği ilgili mefhumun alan çalışmalarına aktarımı ile söz konusu olmuştur. Çoğunlukla kimlik, ben/öteki, güven/güvensizlik, kaygı, rutin, öz-anlatı, öz-imaj gibi temalar etrafında şekillenen OGT'nin U.İ. alanındaki çalışmalar açısından kapsayıcılığ 1 günden güne artmaktadır. Bununla birlikte, halihazırda "dış politika analizi, tanıma/yanlış tanıma ve ulus markalaşma(recognition/misrecognition and nation-branding), duygular, kolektif hafıza, kaygı çalışmaları (affect, Collective memory and anxiety studies) ve eleştirel güvenlik ve barış çalışmaları(critical security and peace studies)" öne çıkan araştırma alanları olarak anılmaktadır (Adısönmez \& Rumelili, 2020, s.11). Mevcut çalışmanın sınırlılıklarından ötürü, söz konusu kavram ve teorik yaklaş1mın detaylarına ve U.İ. disiplininde ne gibi bir boşluğu doldurduğu meselesine burada uzun uzadıya değinilemeyecek olsa da alanda doğrudan bu kavram ve ilgili literatüre odaklanan değerli çalışmalar mevcuttur. (bknz. 
Mitzen, 2006; Steele, 2008; Kinvall \& Mitzen, 2016; Mitzen \& Larson, 2017; Adısönmez \& Rumelili, 2020; Sarı Ertem \& Düzgün, 2021) Bununla birlikte, fikir vermesi açısından birkaç örnekten yola çıkarak ontolojik güvenlik meselesinin U.İ. disiplini ile ne şekilde ilişkilendirildiğinin kabaca da olsa bir resmi çizilebilir. Bu kapsamda, örneğin Hansen (2016)'ın çalışmasında, Rusya'nın Batı ile ilişkilerinde mevcut olan ötekileştirici anlayışa değinerek ikili ilişkiler özelinde var olan Öteki vurgusunun ontolojik güvenliğe ve Rus kimliğinin pekiştirilmesine katkısının değerlendirildiği görülür. Bir diğer örnekte Gustafsson (2013), Çin ve Japonya'nın ikili ilişkileri özelinde bir değerlendirmede bulunularak devletlerin kimi durumlar özelinde karşılıklı olarak inşa ettikleri algıları ele almış ve öz-anlatıların sarsılmasından duyulan endişeyi ikili ilişkilere etki eden bir ontolojik güvenlik olgusu olarak irdelemiştir. Firoozabadi (2011), İran'ın Irak ile savaşında takındığı tavır ve ABD ile süregelen gergin ilişkisinin nedenlerini ontolojik güvenlik bağlamında detaylandırmıştır Behravesh (2018), İran nükleer enerji meselesi sürecine odaklandığ 1 çalışmasında, İran'ın meseleyi yönetim biçimini ontolojik güvenlik ve devlet revizyonizmi bağlamında gözden geçirmiştir. Darwich (2016), uluslararası politikada kimliksel benzerlikler devlet adına ilişki kurmayı ve geliştirmeyi kolaylaştırıcı, işbirliği ortaya çıkaran bir faktör olarak değerlendirilse de özellikle Orta Doğu coğrafyası göz önünde bulundurulduğunda aksi örneklere sıkça rastland1ğından söz etmiş ve bu yönde gelişen devlet davranışlarının ele alınmasında ontolojik güvenlik literatürünün açıklayıcılığına değinen bir çalışma ortaya koymuştur. Zarakol (2010), devletlerin kendilik algılamalarının ve öz-anlatıların sürekliliği vurgusundan yola çıkarak geçmiş hataların kabulü hususunu devletlerin ontolojik güvenliği ile ilişkilendirmiş ve ülkelerin ikili ilişkiler adına önemli bir kazanç sağlayacak ya da maddi bir zarar ortaya çıkarmayacak olmasına karşın devletlerin özür dileme konusundaki isteksizliklerini ontolojik güvenlik kaygısıyla açıklamıştır. Bu gibi pek çok çalışma, ontolojik güvenlik meselesinin devlet davranışları, dış politikaları ve karş11ıklı ilişki biçimleri üzerinde ne gibi bir etkinliği bulunduğu sorusuna yanıt bulmak adına önemli katkılarda bulunmuştur.

Özetle, ontolojik güvenlik incelemeleri devletlerin 'rasyonel' kabul edilmeyen ya da fiziksel güvenliği ve materyal çıkarı öncelemeyen davranışlarını değerlendirmek adına dikkate değer bir açıklayıcılık ortaya koymaktadır. Bir diğer deyişle, devletlerin güvenlikleri mevzubahis olduğunda geleneksel olarak onların fiziksel ve materyal çıkarlarıyla ilişkili bir güven- 
lik olgusuna atıfta bulunulmaktayken yakın zamanda ontolojik güvenlik kavramının da disipline dahil olması, bu çerçevede yürütülecek çalışmalar adına yeni bir perspektif ortaya çıkarmıştır. Bu çalışma, söz konusu perspektifin İran dış politikasında süreklilik arz eden ve çoğu zaman 'rasyonel' olarak değerlendirilemeyen kimi hususları anlamlandırmak adına da önemli bir katkıya sahip olduğu fikrinden hareket etmektedir. Bu doğrultuda, çalışmanın izleyen kısmında İran'ın ne gibi bir kendilik kavrayışına ve öz-anlatıya sahip olduğuna değinilecek ve bunun bir yansıması olarak ontolojik güvenlik algısından söz edilerek İsrail ve Filistin özelindeki politikalar üzerinden bir değerlendirme yapılmaya gayret edilecektir.

\section{3. İran Dış Politikasında Ontolojik Güvenlik Arayışı}

Bugüne dek psikoloji, sosyoloji, felsefe başta olmak üzere pek çok farkl1 disiplin dahilinde ele alınmış olan kimlik (identity), ben (self), öteki (other) gibi kavramların sosyal bilimler çalışmalarına dahil oluş serüveninde William James'in 'The Principles of Psychology (1890)' adlı eserinin önemli bir konuma sahip olduğu kabul edilmektedir. James(1983)'e göre (akt. Beer, 2012, s.330), benlik ancak algılayan ve algılanan olarak benin gelişimine katkı sunan evrelerin nitelendirilmesiyle anlaşılabilir. Ona göre (akt. Beer, 2012, s.330), örneğin "bir eliyle diğer el bileğini kavramakta olan kişi bir yandan algılanan diğer yandan ise algılayandır" ve ben'in meydana gelişinde bu iki algıya da ihtiyaç vardır. Kimlik kavramının sosyal bilimler alanındaki ilerleyişinde önemli paya sahip diğer bir isim olan Erikson (1968, s. 130)'a göre ise, varoluşsal olarak sosyallikle çevrelenmiş olan insan, kimlik duygusu olmaksızın bir yaşarlık duygusuna da erişemez. Ona göre, kimlik "eş zamanlı iki gözlem üzerine kuruludur: kişinin kendi varoluşuna dair zamansal ve mekansal sürekliliğinin algılanması ve kişinin aynılık ve devamlılığının başkalarınca tanındığı gerçeğine dair bir algının var olması" (Erikson,1968, s. 50). Kimlik olgusunun Uİ çalışmalarına kal1c1 olarak dahil olma sürecinde ise İnşacılık (Constructivism)'ın önemli bir rolü bulunmaktadır. Devletler adına kimlik, çıkar, eylem ilişkisine vurgu yapan ve kimliği sosyal etkileşim temelli sürece yayılmış bir karşı1ıklı inşa olgusu olarak değerlendiren bu teorik perspektif uyarınca kimlikler, devlet eylemleri ve uluslararası politikanın işleyişi üzerinde önemli bir etkinliğe sahiptir. Bu yaklaşımın öncü isimlerinden Wendt (1992, s. 398)'e göre, sosyal inşa süreçleriyle mevcudiyet kazanan "kimlikler çıkarların temeli- 
dir." Ona göre, "[k]imlikler aktörlerin kim ya da ne olduğuna işaret eder. (...) Çıkarlar aktörlerin ne istediğine işaret ederler. (...) Çıkarlar olmadan kimliklerin güdüleme gücü yoktur, kimlikler olmadan çıkarların yönü yoktur" (Wendt, 2012, s. 287-288). Dolayısıyla sosyal inşacı bir perspektiften değerlendirildiğinde devletlerin izlemekte olduğu politikalar onların kimliklerinden bağımsız değildir. Barnett (2002, s. 62) de, kimliklerin mevcudiyetinin sosyallikle doğrudan ilişkili olduğuna değinerek devletlerin diğer devletlerle geliştirdiği karşılıklı ilişki ve etkileşimlerin devlet kimlikleri adına tanımlayıcı bir rol üstlendiğinden ve tüm siyasal kimliklerin diğerleriyle olan etkileşim ve rollere bağlı olduğundan söz eder. OGT ise, devletlerin kimlikleri, kaygıları, rutinleri, tutumları, sosyallikleri arasında bir bağıntı kurarak devlet eylemlerini kimliksel kaygı ve güvenlik odağında ele almamiza olanak sunar.

Giddens (2019, s. 171)'a göre, “[b]ireylerin gündelik hayatlarında belirli zamansal ve mekânsal patikalardan geçerken izledikleri rutinler bu hayat1 "normal" ve öngörülebilir" k1lar." 1979 devrimi ile birlikte yeni bir kendilik tasavvuruna sahip olan İran da bir yandan fiziksel güvenliğine ve materyal çıkarına yönelik politikalar izlerken öte yandan yeni rejim kimliğini de kimi alışkanlıklar ve rutinler vasıtasıyla güvende tutmaya gayret etmiştir. Ben (self) ve Öteki (other) ayrımına yapılan vurgu İran dış politikasının genel işleyişinde ve siyasilerin söylemlerinde sıklıkla öne çıkarılan bir tema haline getirilirken, rejimin kimliğin ve inşa edilen öz-anlatıların sürekliliği ise izlenen politikalar aracılığıyla pekiştirilmeye ve temin edilmeye çalışılmıştır.

1979 devrimi ile birlikte büyük ölçüde yeni bir öz-anlatıya ve kendilik tasavvuruna sahip olan İran, kendisini mazlumları İslam öncülügünde refaha erdirecek olan devrimsel sarsıntının başladığı yer ve bu bağlamda ezilen halkların savunucusu ve yol göstericisi olarak addederken, anayasasında da kendine yer bulan müstekbir (kendini üstün gören/ezen)/ müstazaf (küçük görülen/ezilen) ayrımı meselesini dış politikasının başlıca söylemlerinden biri haline getirmiştir. Saideman (2002, s. 184-195)'a göre, İran kimliğini siyasal İslam, tarihsel milliyetçilik ve emperyalizm karşıtllı̆ı bileşenleri özelinde değerlendirmek mümkündür. Ehteshami (2002, s. 284285) de hem tarihsel süreçte inşa olan yabancı müdahaleciliğine ilişkin kaygının hem de "İran-merkezli dünya" düşüncesinin İran dış politikasına ilişkin fikir sahibi olmak noktasında önemli birer kimliksel unsur olarak 
göz önünde bulundurulması gerektiğinden söz eder. Bununla birlikte, Maloney (2002, s. 94-102)'e göre İran kimliksel olarak “"“büyük güç” milliyetçiliği, İslam ve emperyalizm karşıtlığı" gibi bileşenlere sahip olmakla birlikte bilhassa kimliğinin İslam bileşenini öne çıkararak kendine bu konuda önemli bir rol biçmiştir.

Humeyni'nin yorumlayarak yeni rejime uyarladığı velayet-i fakih doktrini çerçevesinde İran, Mehdi'nin dönüşüne dek yeryüzünde adaletin temini ve müstazafların gözetimi konusunda gayret etme sorumluluğunu üstlendiğini beyan etmiştir. İran'ın tüm Müslümanların savunucusu ve müstazaf halkların daimî destekleyicisi olduğu ve zorbaca faaliyetlerin karşısında durmayı ilke edindiği hususuna anayasada da yer verilmiştir (bknz. İran İslam Cumhuriyeti Anayasas1, 1989, Md.152 ve Md. 154). Bu bağlamda, zulme, kibre karşı direniş ve adalet söylemi devrimden bu yana İran'ın kendilik imajının ve öz-anlatısının temel birer eşlikçisi olmuştur. Bu doğrultuda, Filistin meselesi İran resmi makamlarınca her firsatta İslam aleminin sahiplenmesi gereken birincil mesele olarak lanse edilmiştir (IRNA, 6 Aralık 2017). İran'ın Filistin meselesi ekseninde üstlendiği rol, rejimin kimliksel ilkeleriyle doğrudan örtüsşen bir özelliktedir. Ayetullah Humeyni, "Filistin halkını desteklemeyi, İan İslam Cumhuriyeti'nin 'ideolojik, itikadi ve yasal olarak da siyasi bir konusu' olarak kabul” etmiştir" (Mehr Haber Ajans1, 28 Nisan 2012). Devrim rehberi Ayetullah Hamaney, "İran'1n Filistin meselesindeki tutumunun kati ve ilkesel olduğunu belirterek, İslam Devrimi'nin zafere ulaşmasından bu yana bu tutumda değişiklik olmad1ğını" ifade etmiştir (IRNA, 15 Kasım 2019). Meselenin öncelikli muhatab1 olan İsrail her firsatta İran'1n sert söylemlerine konu olmuş, istikrarlı biçimde Öteki (other) olarak muamele görmüştür. Her yıl 'Küresel Emperyalizmle Mücadele Günü' gibi etkinliklerde de söz konusu olduğu biçimde, ABD ile birlikte daima İranlı siyasilerin eleştirilerinin odağında yer almıştır (bknz. Pars Today, 4 Kasım 2017). Beşiriye (2009, s. 74) Ben ve Öteki arasındaki temastan ““"kendine özgü” düşmanını bulmak, inşa etmek ve bu öteki ile mücadele ederken kendi kimliğini oluşturmak" olarak söz etmektedir. Bu bağlamda İran, devrimin ardından ABD'yi büyük şeytan (great satan) ilan ederken İsrail'i ise küçük şeytan ilan etmiş ve Siyonist rejim olarak bahsetmeyi seçtiği ve halen tanımadığı İsrail devletine ABD ile birlikte Öteki (other) olarak muamele etmiştir. Dolayısıyla, İran Filistin meselesinde takındığı tavır doğrultusunda, ABD'nin bölgedeki kuklası ve işbirlikçisi olarak söz ettiği İsrail'in varlığını ve politikalarını reddetmekte 
ve böylece 'hegemonyaya karşı' ve 'mazlumların savunucusu' olmaya ilişkin öz-anlatılarını pekiştirmektedir.

Esasen, Maloney (2002, s. 108)'in belirtmiş olduğu üzere devletlerin başlangıçtan itibaren kendilerini hangi kimliksel özelliklerle tanımlıyor oldukları "geleceğin politika yapıcılarının, sapmayı siyasi olarak acı verici bulabileceği yol bağımlılıkları oluşturur." Hinnebusch (2003, s. 94) da bu durumu "rol bir kez kurulduğunda ve gelecek nesil politika yapıcıların sosyalleşmesini şekillendirdiğinde, bir dereceye kadar seçkinleri sınırlayan, liderlik ve çevre değişikliklerine rağmen diş politikaya belirli bir tutarlılık kazandıran meşruiyet ve performans standartlarını belirler" sözleriyle ifade etmiştir. İran'ın kendisini Müslüman milletlerin savunucusu, müstazafların destekleyicisi vb. öz-anlatılarla tanımlaması ve onun kendine biçmiş olduğu rol, dış politikası üzerinde önemli bir belirleyiciliğe sahip olmuştur. Böylelikle İran, İsrail'in varlığı ve Filistin meselesinin çözümü noktasında sıra dışı bir tavır benimsemiş, süreç içerisinde kendisini bu hususta Filistinlilerden dahi boyun eğmez bir pozisyonda bulmuştur (Maloney, 2002, s. 108).

Keddie (1988, s. 311)'nin de belirttiği üzere, müstekbir/mustazaf ayrımına yapılan vurgu aynı zamanda hegemonya karşıtlığı düşüncesi ile de örtüşmektedir. Özellikle on dokuzuncu yüzyıl başlarından itibaren dikkat çekici bir hal alan bölgesel büyük güç çekişmeleri (bknz. Erkan, 2010a; 2010b), İran için hegemonya karşıtlığının kimliksel bir bileşen olarak gelişimine katk1 sağlamış (Maloney, 2002; Ehteshami, 2002, s. 284-285; Saideman, 2002, s.179), devrim sonrası İran'ının hegemonya karşıtlığı üzerinden bir öz-anlatı sahiplenmesinde oldukça belirleyici olmuştur. İran'ın hegemonya karşıtı söylemle pekiştirdiği bir öz-anlatıya sahip oluşu onun kendine biçmiş olduğu müstazafların savunucusu imajına da katkı sunmuştur. İran'ın öz-anlatılarına katkı sunan rutinleri mümkün mertebe sürdürme gayretinde olduğu görülmektedir. Bu doğrultuda İran, İsrail'i Batılı emperyalistlerin ekonomik ve siyasi hegemonya faaliyetlerinin eşlikçisi olarak betimlerken Filistinlileri ise müstekbirler karşısında zulme uğrayan ve İran'ın kol kanat germesine muhtaç mustazaf bir millet olarak tasvir etmiştir. Devrimin kurucu rehberi Ayetullah Humeyni "biz mazlum ve mahrum halkı kurtarmakla vazifeliyiz. Biz mazlumlardan yana ve zalimlere düşman olmakla mükellefiz" (Humeyni, t.y., s. 49) derken; mevcut rehber Hamaney ise, İran'ın "ne pahasına olursa olsun" "istikbarın zulmüne uğramış mağdur" 
halkların yanında olacağını sıklıkla ifade etmiştir (Hamanei, 2018, s. 133). Domazeti (2018)'nin de belirttiği gibi, bu anlayış İran'ın 1979 devrimi sonrası bölgeye yönelik politikasını biçimlendiren faktörlerden biri olmuştur. İran dış politikasında dikkat çeken bu anlayış özellikle Filistin meselesine yaklaşım hususunda devrimden bu yana özenle sürdürülmüş, mevcut dış politik işleyiş dahilinde ontolojik güvenliğin temini adına tekrarlı bir yapı arz etmiştir.

\section{4. İran'ın Filistin Meselesine Yaklaşımı}

İran'ın 1979 sonrasında Filistin meselesine ilişkin ne gibi bir tavra sahip olacağ devrim öncesi dönemden itibaren Ayetullah Humeyni'nin meseleye olan yaklaşımıyla açıkça belirlenmiştir. Bu hususta pek çok beyanatta bulunan Humeyni, İsrail'e olan karşıtlığını ve Şah'a olan muhalefetini de her firsatta yinelemiştir. Yanı sıra, İsrail ile anlaşma sağlamayı da haram olanak nitelendirmiştir (Biçen, 2017, s. 75). '15 Hordad kıyamı' (15 Hordad 1342- 4 Haziran 1963) olarak anılan evrede, İsrail ile olan yakın ilişkileri nedeniyle Şah Muhammed Rıza Pehlevi’yi sert dille eleştirerek “yoksa Şah, İsrailli midir?" (Tasnim Haber Ajans1, 4 Haziran 2018) diyen Humeyni, İsrail'e petrol satan Şah rejimini İslam'a aykırı davranıyor olmakla suçlamış ve bu gibi söylemleri devrime dek sürgünde kalmasıyla sonuçlanmıştır (Cleveland, 2008, s. 326-327). Bu süreçte, inançlı her kimsenin direnen Filistin halkının davasına destek olması gerektiğine dair bir fetva da yayınlayan Humeyni, İran'da her yıl toplanan hums ${ }^{1}$ 'un bir miktarının Filistin davasına sahip çıkan mücahitlere(Şii olmamalarına karşın) iletilmesini salık vermiştir (Saad-Ghorayeb, 2013, s. 5).

İran, devrim öncesi evrede İsrail ile jeostratejik ve ekonomik ilişkiler geliştirme hususunda istekli ve girişken bir tavır içerisindeyken, 1979 devrimi ile birlikte bu durum tümüyle tersine evrilmiştir. Bölgenin genel dokusundan ayrılan özellikleriyle dikkat çeken iki ülke, devrimden önceki süreçte işbirliği geliştirmek konusunda sorun yaşamamıştır. Anılan süreçte İsrail, İran petrolü için önemli bir pazarken, İran ise İsrail ürünlerinin önemli alıcılarından biri olmuştur. Ancak her iki taraf için de kârlı kabul edilen bu ilişki, İran tarafından İslam devrimiyle birlikte kasıtlı biçimde ortadan kal-

Elde edilen kazancın beşte birlik kısmının vergi olarak doğrudan din adamlarına ödenmesini ifade etmektedir. 
dırılmıştır. Karşılıklı ilişki geliştirmenin olası avantajları bulunsa da İran'ın İsrail'e yönelik ötekileştirici ifadelerinde ve bu ülkeye yönelik tavrında o günden bu yana bir değişiklik yaşanmamıştır. Daha devrim sürecinin başında, İran rejim yanlılarının ele geçirdiği İsrail elçilik binasının Filistin elçiliği olarak kullanılmak üzere Filistinlilere armağan edildiği bildirilmiştir (Tasnim Haber Ajans1, 23 Haziran 2017). 7 Ağustos 1979 tarihinde ise, Ramazan ayının son Cuma'sı Ayetullah Humeyni tarafından "Dünya Kudüs Günü" olarak ilan edilmiş ve Humeyni söz konusu güne ilişkin fikirlerini, "İran (...) her şeytani güce karşı durarak mazlumları savunmaya (...) Kudüs’ü desteklemeye kararlıdır. (...) Kudüs günü sadece Filistin günü değildir, (...) İslam ülkelerinde artık ilerleyemeyeceklerini süper güçlere anlatma günüdür" (IRNA, 31 Mayıs 2019) diyerek ifade etmiştir. İran resmi söylemince, "Filistinlilerin direnişi tüm Müslümanların ve bağımsızlık arzu eden toplumların onur kaynağıdır ve İran Filistin halkını zafere kadar destekleyecektir" (Mehr Haber Ajans1, 13 Eylül 2008). İran'ın Filistin'e desteğinden ötürü çeşitli baskıların hedefi olduğunu belirten Ayetullah Hamaney ise, meseleye bakışını “(b)u baskılar asla bizi Filistin'e destek konusunda dini, ilahi ve akli vazifemizden vazgeçiremez" (Pars Today, 22 Ocak 2021) sözleriyle açıklamıştır. Kısacası, İran hem devrim öncesinde hem de devrim sonrasında Filistin'e olan koşulsuz desteğini her firsatta yinelemekte İsrail'e yönelik olumsuz yaklaşımın Humeyni'nin ölümünden sonra da bilhassa korunmuş olduğu gözlenmektedir.

OGT, ontolojik güvenlik ihtiyacının da eylemler üzerindeki belirleyiciliğini kabul etmekte ve dış politika açısından değerlendirilmesine olanak sunmaktadır. Mitzen (2006a, s. 270-273), varoluşsal açıdan istikrarlı bir kimliğe ihtiyaç duyan aktörlerin bu kimlikleri rutin ilişkiler yoluyla pekiştirdiklerine vurgu yapmaktadır. Ona göre, "devletlerin ontolojik güvenlik aradıklarını varsaymak, neden zaman içinde benzer biçimde davranan fark11 karar alıcılar görebileceğimizi anlamak için sosyolojik bir temel sağlar" (Mitzen, 2006b, s. 353). Keza, 'medeniyetler arası diyalog' söyleminin mimarı olan ve ılımlı dış politika anlayışı ile dikkat çeken Hatemi döneminde dahi, İran dış politikasında son derece radikal adımlar atılmış olsa da Filistin hususunda tavizkâr davranılmadığı görülmektedir. Kendisine, ünlü CNN röportajı esnasında, İran'ın Filistin direnişinde rol oynayan silahlı gruplara mali, moral ve siyasi desteğinin nedeni ile ilgili bir soru yöneltilen Hatemi, bu soruya "toprakları uğruna devlet terörüne karşı mücadele eden mazlum halkların desteklenmesi teröre destek olarak kabul edilemez" 
diyerek yanıt vermiştir (CNN, Ocak 7, 1998). Hatemi dış politikaya olan bakışını, "[d]iyaloğun ilk kuralı... kendinizi ve kimliğinizi bilmektir. İkinci kural bir diyalog sürdürmek istediğiniz medeniyeti bilmektir" (Ansari, 2006, s. 160), "anlamlı bir diyalog ancak ilgili taraflar kendilerini hakiki özsel kültürel alanlarında bulduğunda gerçekleşebilir, aksi takdirde kendine yabancılaşmış bir taklitçi ile diğerleri arasındaki diyalog anlamsız ve kesinlikle herhangi bir yarar veya faydadan yoksun olacaktır" sözleriyle ifade etmiştir (The Iranian News, Aralık 9, 1997).

İran, İsrail ile olan husumetini ve Filistin'e desteğini her dönem çeşitli söylemlerle diri tutmaya gayret etmiştir. Ancak, Mahmud Ahmedinejad döneminde bu söylemlerin sertliğinin daha da ileri taşındığı görülmüştür. Ahmedinejad, "Filistin sorununun ortadan kalkması ve bu doğrultuda "işgal edilen topraklardan Siyonist rejimin yok olması" meselesinin "insani ve uluslararası bir konu olduğunu" (Mehr Haber Ajansı, 14 Aralık 2010) söylemiş, bu gibi sert ifadeler daima İsrail tarafının sert açıklamalarıyla karş1lık bulmuştur (DW, 16 Haziran 2006). Yahudi soykırımı için, Batı'nın bir masalı diyen Ahmedinejad'ın İsrail'in 'yeryüzünden silinmesi gereken bir leke’ olduğuna dair açıllamaları2 küresel alanda da İran'a yönelik çeşitli tepkilere yol açmıştır (The New York Times, Aralık 15, 2005). Ahmedinejad döneminde de İran'ın İsrail rejimine olan karşıtlığı “[b]izim Siyonist rejime karşı olmamız barış ve adalet içindir" (Mehr Haber Ajansı, 25 Eylül 2008) sözleriyle ifade edilmiş ve İran'ın 'zulme karşı adalet arayan ülke' öz-anlatısına vurgu yapılmıştır.

İran, İsrail ve Filistin arasında vuku bulacak bir barış sürecine daima olumsuz yaklaşmış, bu tutumunu özenle korumuştur. Ayetullah Humeyni İran'ın bu husustaki karşıtlığını, söz konusu meselede ortaya atılacak her barış planının ABD planı olacağını ve hem Müslümanların hem de Filistin halkının aleyhinde bir içeriğe sahip olacağını savunarak gerekçelendirmiştir (Taghipour, 1992). Muhammed Hatemi ise, İran'ın Ortadoğu barış görüşmelerine karşıtlığının gerekçesini "Orta Doğu barış sürecine muhalefetimizi ilan ettik çünkü bunun başarılı olamayacağına inanıyoruz" (CNN, 7 Ocak, 1998) diyerek açıklamıştır. 1991 Madrid Konferansı ve 1993 Oslo İlkeler Bildirgesi gibi uzlaşıya dönük girişimler İran tarafından sürekli bir

Ahmedinejad'ın bu açıklamalarının çarpıtıldığı da ifade edilmiştir. İlgili bir çalışma için bknz. (Kessler, 2011). 
biçimde kınanmış ve eleştirilmiştir (IRNA, 30 Aralık 2016). Bu dönem Arap-İsrail barış görüşmelerine tepkiyle yaklaşmış olan İran, buna binaen kendisiyle aynı hassasiyetlere sahip devlet dışı aktörleri de davet ettiği bir konferans düzenlemiştir. 'Filistin İntifadasına Destek İçin Uluslararası Konferans' adı verilen bu girişimin ardından, Hamas ile artacak yakın temasının temellerini atan İran, Filistin direnişine destek veren bu gibi yapılanmalarla ilişkilerini günden güne geliştirmiştir (Şen, 2016, s. 289-291). Seksenli yılların başında Hizbullah'ın kuruluş aşamasında da önemli bir rol üstlenmiş olan İran, doksanlı yılları takiben Hamas ve İslami Cihad gibi Filistin direnişine katkı sunan grupları da askeri, mali, siyasi vb. açılardan desteklemeyi bölgesel dış politikasının ayrılmaz bir bileşeni haline getirmiştir (Sinkaya, 2014, s. 30). Keza, hem Hamas ve Hizbullah liderlerinin yapmış olduğu açıklamalar (Mepa News, 21 Mayıs 2021; Mepa News, 11 Ocak 2020; Khamanei.ir, 1 Ekim 2019), hem de İran resmi makamlarının açıklamalarıyla (Fars News, 13 Temmuz 2021) bu yakın ilişki sıklıkla vurgulanmaktadır.

İran'ın devrimin ardından sahiplendiği söylem tarzı ve politikaları komşu ülkelerle ilişki geliştirmesini de güçleştirmiş ancak her şeye karşın uzunca bir müddet hiçbir geri adım atılmaksızın ilerletilmiştir. Humeyni'nin Dünya Kudüs Günü ile ilgili olarak söylediği, "Kudüs günü sadece Filistin günü değildir, İslam günüdür aynı zamanda İslam devleti günüdür, İslam cumhuriyeti bayrağının bütün ülkelerde dalgalanması gereken gündür" (IRNA, 31 Mayıs 2019) gibi sözleri özelinde de söz konusu olduğu üzere, İran resmi makamlarının kimi ifadeleri komşu devletlerin İran'dan rejim ihraç kaygısı yaşamasına neden olmuştur. Firoozabadi (2011, s. 49)'ye göre, İran'ın o dönem komşu ülkelerin meşruiyetine meydan okuyan ve bu rejimlerin İslamcı devrimci muhaliflerini destekleyen revizyonist tutumu da onun ontolojik güvenlik arayışı ile doğrudan ilişkilidir.

Daha sonra özellikle İran-Irak Savaşı ile birlikte ülkenin uğradığı tahribatı dış politikada daha 1 lımlı ve yapıcı bir süreçle telafi etmeye çalıştığı doksanlar evresi de dahil olmak üzere İran, Filistin meselesine olan dikkati ve adanmışlığının yanı sıra İsrail karşıtı söylem ve politikalarını sürdürmüş ve bu uğurda zaman içerisinde hem yakın komşularıyla hem de Batılı ülkelerle ilişkilerin onarımı adına yürüttüğü kimi girişimleri hiçe saymaktan da çekinmemiştir. İran, doksanlı yıllar itibariyle geliştirmeye çalıştığı 1lımlı dış politika anlayışı doğrultusunda zamanla Körfezdeki Arap ülkeleriyle 
diyaloğunu ilerletmeye çabalamış, Soğuk Savaş öncesinin "ne Doğu ne Batı" (na shargi, na gharbi) anlayışından "hem Kuzey hem Güney" anlay1şına geçildiği görülen bu yeni evrede (Ramazani, 1992) özellikle Batı’ya yönelik kışkırtıcı söylemler terkedilerek bölge ülkeleriyle de iyi komşuluk ilişkileri tesis etme gayretinde olunmuştur. Ancak tüm bu çabaya rağmen, öncesinde 2006 yılında İsrail-Filistin arasında cereyan eden Temmuz Savaşı sırasında, sonrasında ise İsrail'in 2009 Gazze işgali evresinde, İranlı yetkililer Arap komşularını Filistinlilere destek olmadıkları için sert ifadelerle eleştirmekten geri durmamışlardır. Seyyid Ali Hamaney Arap ülkelerini bu mesele karşısında 'ihanet içinde' olmakla ve 'ikiyüzlülük' ile suçlarken, Mahmud Ahmedinejad ise komşularını 'Filistinlilere yönelik soykırım suçunun ortağı' olmakla itham etmiştir (DW, 16 Ocak 2009). Bölgenin diğer ülkelerinin İsrail ile ilişki geliştirmesine de tepkiyle yaklaşan İran, yakın zamanda İsrail ile ikili ilişkilerine normal bir seyir kazandırma girişiminde bulunan iki Arap ülkesi BAE ve Bahreyn'in tutumuna da yoğun bir tepki ile karşılık vermiş (Euronews, 15 Eylül 2020) ve bizzat en üst makamlardan sert açıklamalarda bulunulmuştur (Anadolu Ajansı, 16 Eylül 2020). 28 Ocak 2020 tarihinde ABD öncülüğünde açıklanan "Yüzyılın Anlaşması" adlı tasarı da İran tarafının tepkilerine yol açmıştır. Söz konusu tasarı sonuçsuz kalacağı için, "bu planı açıklamanın ahmakça bir eylem ve karar olduğu[nu]" belirten rehber Hamaney, bu tasarıya destek veren komşu Arap ülkeleri için bir kez daha 'hain' ifadesini kullanmakta beis görmemiştir (IRNA, 5 Şubat 2020). Hatta, bu anlaşmaya cihat yoluyla karşıllık verilmesi gerektiğini söyleyen Hamaney, İran'ın silahlı Filistin gruplarını desteklemeyi görev bildiğini ve bu konuda elinden geleni yapmayı sürdüreceğini beyan etmiştir (ISNA, 5 Şubat 2020).

Devlet dışı oluşumlar ile yakın ilişkilerin İran'a kimi olanaklar sunduğunu söylemek mümkünse de bu politikalar aynı zamanda pek çok problemi de beraberinde getirmiştir. Keza, söz konusu yakın ilişkiler bugüne dek İran'ın başını sıklıkla ağrıtmış, ülkeye yönelik yaptırım uygulamalarının bir ayağını da bu husus oluşturmuştur. İlk kez 1984'te ABD diş işleri bakanlığı tarafindan, 'terörizmi destekleyen ülkeler' arasında gösterilmiş olan İran, o günden bu yana hazırlanan çok sayıda raporda da tekrar tekrar bu kategoride değerlendirilmiş ve bu hususta çeşitli yaptırımlara maruz bırakılmıştır (Küpeli, 2016). ABD, 1995 yılı itibariyle İran'a yönelik uyguladığ ticaret ambargosu (D'Amato Act/Iran Foreign Oil Sanctions Act) ve 1996 yılında devreye alınan İran Libya Yaptırım Yasası (Iran and Libya 
Sanctions Act/ILSA)'nın arkasında İran'ın Filistin meselesi çerçevesinde izlediği politikaların da yer aldığını ifade etmiştir (Satloff, 2002). 2002 yılına gelindiğinde dönemin ABD başkanı George Bush, Hamas, Hizbullah, İslami Cihad vb. gruplarla işbirliği halinde olan ve bu gruplara silah temininde bulunan ülkelerin dünya barışı ve ABD'nin güvenliği açısından büyük bir tehdit oluşturduğunu ve ABD'nin söz konusu durumun ortadan kaldırılması adına gereken her şeyi yapacağını duyurmuş, şer ekseni (axis of evil) içinde tanımladığı İran'ın, anılan gruplara desteğinden ötürü son derece dikkatle izlenmekte olduğunu bildirmiştir (The White House, 2002). 2002 yılı içerisinde Filistin'e yardım götüren ve silah yüklü olduğu belirtilen İran bandıralı bir geminin (Karine-A) İsrail tarafından ele geçirilmesi olayı da ABD'nin İran'a karşı bu hamlesine katkı sağlamıştır (Slavin, 2007 s. 212-213; Ekinci, 2009, s. 283-284). İlerleyen süreçte, 'terörizme en fazla destek veren ülke' olarak beyan ettiği İran'1, İslami Cihad, Hamas, Hizbullah gibi devlet dışı aktörlere silah, ekipman, eğitim ve finansman sağlanmasından başlica sorumlu ülke addeden $\mathrm{ABD}$, bu durumun önüne geçebilmek için 'maksimum baskı' politikası uygulayarak ekstra yaptırımlar işletme kararı almıştır (U.S. Department of the Treasure, 2018; Bureau of Counterterrorism, 2019). Bununla birlikte, ilgili süreçte İran Ulusal Güvenlik Konseyi, İran'ın halihazırda süregelen problemleri ve maruz kaldığ tüm yaptırım uygulamalarına karşın direniş gruplarına ve bilhassa da Filistinli gruplara verdiği desteği sürdüreceğini açıklamıştır (IRNA, 31 Mayıs 2019). Nükleer enerji meselesi çerçevesinde uzun uğraşlar sonucu gelişen 'nükleer uzlaşı süreci' de ABD'nin anlaşmadan çekildiğini açıklamasıyla (The New York Times, May 8, 2018) sekteye uğramış ve bu durum İran'ın içinde bulunduğu kimi güçlüklerin (bknz. Anadolu Ajansı, 7 Mayıs 2020) çözümünü belirsiz bir geleceğe taşımıştır.

Filistin'e desteğini her firsatta vurgulayan İran, 9 Mayıs 1990 tarihinde "Filistin Halkına Destek Yasası" adı verilen bir hukuksal düzenleme de gerçekleştirmiştir. 2017 y1lında bu yasal düzenlemeye bir madde de ekleyen İran, Kudüs'ü İsrail'in başkenti kabul eden ABD kararına karş1lık, Kudüs'ü Filistin'in daimî başkenti olarak kabul ettiğini açıklamıştır (IRNA, 27 Aralık 2017). Ancak, halihazırda yaptırımlardan ötürü ekonomisi zorda olan İran halkının da izlenen tüm bu politikalara zaman zaman tepki sesleri yükselttiği görülmektedir. Yaşanan yüksek işsizlik ve enflasyon ve bunun yol açtı̆̆ 1 ekonomik darboğaz zaman zaman İran yönetici eliti ve halkın kimi kesimlerini karşı karşıya getirmektedir. Bu doğrultuda, 
söz konusu politikaların içeride de bir huzursuzluğu beslediği yanı sıra kimi zaman çeşitli protesto gösterilerine konu olduğu görülmektedir (BBC News, 30 Aralık 2017). Özellikle, 2003 yılında meydana gelen öğrenci protestolarında "Filistin'i boşver, bizi düşün" (Taheri, 2008, s. 341); 2017 y1lında gerçekleşen benzer bir eylemde ise "Ne Gazze ne Lübnan, canım yalnız sana feda İran" (Ruda, 2018) sloganları bu hususta dikkat çekicidir. Bu bağlamda, İran tarafından sarfedilen ‘İsrail’e ölüm' sloganlarının ülkesi adına yararsızlığından dem vuran ve "Filistinlilerden daha çok Filistinli olmamıza gerek yok" diyen İranlı reformist düşünür Ali Rıza Alavi-Tabar da bu sözleriyle, ilgili politik anlayışa olan toplumsal eleştirileri dile getirmiştir (Sadjadpour \& Takeyh, 2005).

Özetlemek gerekirse; 1- İsrail'e yönelik sert söylemler zaman zaman İran'ın askeri müdahale tehditlerine varan söylemlerle karşılaşmasına yol açmaktadır. 2- Bölgede aktif olan gruplarla yakın teması İran adına ekonomik yaptırım ve fiziksel güvenlik tehditleri yarattığı gibi, bu temas ülke imajına, politikalarına ve İran'ın özellikle Batılı ülkelerle ilişkilerine olumsuz tesir etmektedir. 3- İran halkı ülkeyi doğrudan ilgilendirmeyen bu meseleye söz konusu desteğin boyutuna ve bu hususun da katkı sağladığ yaptırımlar ve ekonomik güçlükler başta olmak üzere ödenmek durumunda kalınan maliyetlere zaman zaman tepki gösterebilmekte ve dolayısıyla bu çerçevede izlenen politikalar iç siyasete de olumsuz yansıyabilmektedir.

Hunter (2010, s. 102)'ın da ifade ettiği gibi, İran'da 1979 devrimi ile işbaşına gelen rejimin meşruiyet sağlamak ve kendilik imajını sürdürmek maksadıyla Filistin meselesi gibi hususlara yönelttiği dikkat ve çaba, nihayetinde İran dış politikası adına çok çeşitli zararlar doğurmuştur. İran'ın, kimi zaman fiziksel güvenliğine ve materyal çıkarına aykırılık teşkil ettiği durumlarda dahi, izlediği politikalarda 1srarc1 olduğu görülmektedir. OGT'ne göre devletler zaman zaman fiziksel güvenliğini riske edecek biçimde öz-anlatılarının sürekliliğini sağlayıcı eylemlerde bulunabilmektedir (Mitzen, 2006b). Kimlik, devamlılığının bir ön koşulu olarak onu güçlendirici, hatırlatıc1, vurgulayıcı faktörlere ihtiyaç duyduğu oranda kimi devlet eylemleri üzerinde de belirleyicidir. Steele (2008, s. 148), ontolojik güvenliğe duyulan ihtiyacın, devletleri eylemlerini kendi kimlik ihtiyaçlarına göre, "bazen de maddi olarak maliyetli yollarla" yapılandırmaya yönlendirdiğini ileri sürer. Geleneksel yaklaşımlar dışında yeni bir perspektif sunan ve fiziksel ve materyal güvenliğin yanı sıra ontolojik güvenliğin 
de bir dış politika olgusu olarak analize dahil edilmesini mümkün kılan OGT'nin, İran'ın bu hususlardaki ssrarına ilişkin görece daha tatmin edici bir açıklama sunabildiği anlaşılmaktadır. OGT, İran'ın kimliği ve eylemleri arasındaki doğrudan ilişkiyi fark etmemize olanak sağladığı gibi onun Filistin meselesine ve İsrail'e yönelik politikasını farklı bir açıdan keşfetmemizi mümkün kılmaktadır. Dolayısıyla, bu perspektiften bakıldığında, İran'ın Filistin'e olan desteğinin ve bu mesele etrafındaki politikalarının her koşulda sürdürülüyor oluşunun onun ontolojik güvenliği açısından gözardı edemediği bir durumu işaret ettiği görülmektedir. Bir diğer deyişle, söz konusu 1srarlı politikaları gözden geçirerek ontolojik güvenlik bağlamında bir değerlendirme yapıldığı takdirde, İran'ın öz-imajını muhafaza etme ve öz-anlatılarını sürdürme gayesinin bu meseleye ilişkin güçlü bir direniş gayreti yarattığı ve buna ilişkin kaygıların eylemleri biçimlendiren bir ontolojik direnç meydana getirdiğini söylemek olanaklıdır.

Kısacası, İran'ın Filistin meselesi ile olan yakın teması ve İsrail'i hedef alan politikaları ona kimliğini çeşitli açılardan pekiştirme ve özanlatılarının devamlılığını sağlama firsatı vermektedir. 'Zalim' İsrail rejiminin zorbalıkları karşısında ezilen mazlum Müslüman Filistin halkının destekçisi olma söylemini ve bu bağlamda diğer Müslüman halkları da kendince İslam medeniyetinin en öncelikli konusu addettiği bu hususta benzer bir çaba üstlenmeye teşvik etme rolünü benimseyen İran, bu sayede hem müstekbirler karşısında müztazafların savunucusu rolünü vurgulama ve Mehdi'nin dönüşüne değin Şii ya da Sünni tüm dünya Müslümanlarının önderi ve destekçisi olma misyonunu üstlendiğinin altını çizme firsatına kavuşmakta hem de yeryüzünde adil bir düzenin mümkün mertebe sağlay1c1sı olmaya ilişkin öz-anlatısını pekiştirebileceği bir alana sahip olmaktadır. Bu husustaki politikaları ayrıca onun hegemonya karşıtlığı imajına da katk1 sunmaktadır. Yanı sıra, İran'ın Filistin meselesi de dahil olmak üzere bölgede cereyan eden gelişmelerle yakın temas halinde olma gayreti ve bu hususta gerek ekonomik gerekse siyasal anlamda kendi gücünün ve kapasitesinin sınırlarını zorlayan bir yaklaşım içerisinde olması, İran'ın 'güçlü bir imparatorluk geçmişine sahip köklü bir medeniyetin mirasçısı' olmaya ilişkin öz-anlatısı ile de örtüşmektedir. Dolayısıyla İran, Filistin meselesini öncelikli olarak sahiplenmiş ve rejim kimliğinin ve öz-anlatılarının önemli pekiştirenlerinden biri olarak ontolojik güvenliğine katkı sunan bu meseleye dair ilgisini devrimden bu yana muhafaza etmiştir. Bu doğrultuda, İsrail'in ötekileştirildiği bir anlayışla Filistin'e olan desteğin, İran adına 
öteden beri sürdürülen bir "ontolojik güvenlik sağlayan rutin" (Mitzen, 2006, s. 346; Kinnvall \& Mitzen, 2017, s. 3-11) vazifesi üstlendiğini söylemek mümkün görünmektedir.

\section{Sonuç}

OGT, dış politikaya ilişkin karar ve uygulamalar noktasında fiziksel güvenlik kadar ontolojik güvenliğin de etkinliğinden söz etmemize ve bu bağlamda devletler tarafindan çeşitli maliyetlere katlanmak pahasına da olsa sürdürülen kimi dış politika uygulamalarını anlamlandırmamıza olanak sunmaktadır. OGT odağında yürütülen bu çalışmada, ontolojik güvenlik meselesinin İran diş politikasında süreklilik arz eden hususlar üzerinden irdelenmesi amaçlanmış ve bu bağlamda İran'ın İsrail'e yönelik tutumu ve Filistin meselesi odağında izlediği politika özelinde bir değerlendirme gerçekleştirilmiştir.

Dış politika değerlendirmelerinde yararlanılan diğer teorik yaklaşımlardan farklı olarak OGT bize devletlerin ontolojik güvenlik ihtiyaçlarının da eylemleri açısından bir motivasyon sağlayıcısı olduğunu anlatır. Dolayısıyla dış politikanın işleyişinde fiziksel güvenlik ve materyal çıkar odaklı eylemlerin yanı sıra kimliğe ilişkin güvenlik ihtiyaçlarından doğan uygulamalara da rastlamanın olası olduğunu belirtir. Şüphesiz ki her siyasal oluşum birtakım kendilik betimlemelerine sahiptir ve anılan betimleme kendini Öteki'nin sınırlarından mümkün mertebe yalıtan bir anlayışı beraberinde getirir. İran 1979 devrimiyle birlikte büyük oranda yeni bir kendilik tasavvuruna kavuşmuş ve böylelikle kendi Öteki'sini de yeniden tanımlamıştır. Bu çerçevede, ABD ve İsrail gibi ülkelere yönelik politikaları ve kimi meselelere olan yaklaşımı öz-anlatıların sürekliliğinde ve ontolojik güvenliğin temininde önemli bir dayanak noktası teşkil etmiştir. İran rejiminin Öteki'si olarak kurgulanan Batı ve onun değer ve uygulamalarının reddi, İran için ontolojik güvenliğin sağlanması ve sürdürülmesinde öncelikli bir yere sahip olmuştur. Bu doğrultuda, İsrail rejiminin bölgedeki mevcut varlığ 1 ve süregelen uygulamaları da İran tarafından aynı zamanda Batı anlayışının bir ürünü ve yansıması olarak değerlendirilmiş ve bu kapsamda muamele görmüştür.

Devrimden bu yana hem Filistin meselesine olan dikkati hem de İsrail'e yönelik tavrından ödün vermeyişiyle çeşitli maliyetleri göze alan İran, 
devrimden önce İsrail ile jeostratejik ve ekonomik açıdan iyi ilişki içerisinde bulunmayı ve ikili ilişkilerin olumlu seyrini materyal çıkarı açısından faydalı bulurken, 1979 devrimiyle inşa edilen kimliksel yapı bu mantıksal ilişkinin devamına imkân tanımamıştır. İran, İsrail karşıtlı̆̆ 1 bağlamında gerektiğinde komşularına ve diğer ülkelere yönelik sert söylemlerde bulunmaktan çekinmediği gibi genel bir diş politik esneklik geliştirmeye ça1ıştığ 1 evrelerde dahi, inşa etmeye çabaladığ 1 kimi köprüleri bu uğurda yıkmaktan imtina etmemiştir. İran, İsrail rejiminin mevcudiyetini emperyalist, kibirli ve zalim devletlerin, mazlum Müslüman halklara reva gördüğü zulüm olarak beyan etmiştir. Bu denklemde İran İslam Cumhuriyeti kendini Filistinliler başta olmak üzere tüm mustazaf halklar için umut olarak addetmiş ve İran'ın tam da bu sebeple emperyalist baskıların hedefi olduğu söylemini benimsemiştir (bknz. Hamanei, 2018, s.157-158). Bu söylemin eşlik ettiği anlayış, zaman zaman İran'ın kimi dış politika uygulamalarının gerekçesini oluşturmuş̧tur. Kısacası, İran'ın ABD'nin yanı sıra İsrail ile arasında hüküm süren gergin ilişki ve Filistin meselesine olan yaklaşım bir yandan İran adına kimi endişe ve kayıplar doğururken bir yandan da mevcut rejim kimliğinin pekiştirilmesinde ve öz-anlatıların ve öz-imajın sürekliliğinde önemli bir role sahip olmuştur. Dolayısıyla, İsrail'in vazgeçilmez 'Öteki' olarak tanımlandığı bu yeni yapıda, Filistin meselesine yaklaşım ve İsrail'e yönelik tavrın İran için ontolojik güvenliğin temini noktasında önemli bir vazife üstlendiği görülmektedir.

İran'ın, özellikle Batılı ülkeler ile ilişkileri bağlamında dış politikasına olumsuz tesir ettiği kadar iç politikasında da belli başlı sorunlar yaşamasına neden olan, kimi zaman yaptırımlar kıskacında ekonomisini zora sokarken kimi zaman da fiziksel güvenliğine yönelik tehditlere sebebiyet veren dış politika uygulamalarında neden ısrarcı olduğu sorusunu sorduğumuzda geleneksel yaklaşımlar bu konuda tatmin edici bir yanıta ulaşmamızı mümkün kılmazken, OGT bu tutumları "ontolojik güvenlik sağlayıcı rutinler" (Mitzen, 2006, s. 346; Kinnvall \& Mitzen, 2017, s. 3-11) çatısı altında anlamlandırmamıza olanak sunmaktadır. Böylece, geleneksel yaklaşımların devlet davranışları hususundaki genelleştirici öngörülerine karşı bir sav ileri süren bu yaklaşımın, ontolojik güvenliğin de İran için en az fiziksel güvenliğin ve materyal çıarın gözetimi kadar önemli olduğunu ve bu oranda dış politikasına sirayet ettiğini fark etmemiz açısından bir anahtar vazifesi gördüğünü belirtmek olanaklıdır. 


\section{Beyan}

$\mathrm{Bu}$ makale etik kurul kararından muaftır. Çalışmada katılımcı bulunmamaktadır. Çalışma için herhangi bir kurum veya projeden mali destek alınmamıştır. Çalışmada kişiler ve kurumlar arası çıkar çatışması bulunmamaktadır. Telif hakkına sebep olacak bir materyal kullanılmamıştır.

\section{Disclosure}

The article is exempt from the Ethics Committee Decision. There are no participants. The author received no financial support from any institution and there's no conflict of interest. No material subject to copyright is included. 


\section{Kaynakça}

Anadolu Ajans1. (2020, Eylül 16). İran cumhurbaşkanı Ruhani: Bazı Arap ülkeleri, bölgede İsrail'e üs vermek istiyor ancak sonuçlarından sorumlu olacaklar. https://www.aa.com.tr/tr/dunya/iran-cumhurbaskani-ruhani-bazi-arap-ulkeleri-bolgede-israile-us-vermek-istiyor-anca k-sonuclarindan-sorumlu-olacaklar/1975041

Anadolu Ajans1. (2020, May1s 7). Iran ekonomisi ABD yaptırımlart ve koronavirüs klskacında. https://www.aa.com.tr/tr/dunya/iran-ekonomisiabd-yaptirimlari-ve-koronavirus-kiskacinda-/1832189

Ansari, A. M. (2006). Iran and the US in the shadow of 9/11: Persia and the Persian question revisited. Iranian Studies, 39(2), 2006, 155-170. https://doi.org/10.1080/00210860600628716

Barnett, M. (2002). The Israeli identity and the peace process: Re/creating the un/thinkable. İçinde S. Telhami, S. \& Barnett, M. (Ed.), Identity and foreign policy in the Middle East (s. 58-88). Cornell University Press.

BBC News. (2017, Aralık 30). 5 soruda İran'da hükümet karşıtı gösteriler. https://www.bbc.com/turkce/haberler-dunya-42522004

Beer, J. S. (2012). Self- evaluation and self-knowledge. In Fiske, S.T. \& Macrae, C.N. (Ed.), The sage handbook of social cognition (s. 330349). SAGE Publications.

Behravesh, M. (2018). State revisionism and ontological (in)security in international politics: The complicated case of Iran and its nuclear behavior. Journal of International Relations and Development, 21(4), 836-857. https://doi.org/10.1057/s41268-018-0149-x

Beşiriye, H. (2009). İran' da siyasal ideoloji ve toplumsal kimlik. İçinde Hamid Ahmedi (Ed.), Iran: ulusal kimlik inşası (s. 73-87). Küre Yayınları.

Biçen, G. (2017). Ayetullah Humeyni'nin 1980 öncesi söyleminde İran İslam İnkılabı'nın meşruiyet temeli olarak siyonist rejim problemi. Iran Çalışmaları Dergisi, 1(1), 52-83. https://dergipark.org.tr/tr/pub/ iranian/issue/30182/301938

Celalifer E. A. (2009). Iran nükleer krizi. USAK Yayınları. 
Cleveland, W. L. (2008). Modern Ortadoğu tarihi. (Çev. M. Harmanc1). Agora Kitaplığ1. (Orijinal yayın tarihi 2004)

CNN. (1998, Ocak 7). Transcript of interview with Iranian president Mohammad Khatami. http://edition.cnn.com/WORLD/9801/07/iran/ interview.html

Darwich, M. (2016). The ontological (in)security of similarity Wahhabism versus Islamism in Saudi foreign policy. Foreign Policy Analysis, 12(3), 469-488. https://doi.org/10.1093/fpa/orw032

Domazeti, R. (2018, Eylül 19). İdeoloji ile jeopolitik gerçekler arasında İran'ın Filistin politikaları. Insamer. https://insamer.com/tr/ideoloji-ile-jeopolitik-gercekler-arasinda-iranin-filistin-politikalari_1625. html\#_edn48

DW. (2006, Haziran 16). Ahmedinejad: öneri paketi ileri bir adım. https://www.dw.com/tr/ahmedinejad-\%C3\%B6neri-paketi-ileri-bir$\mathrm{ad} \% \mathrm{C} 4 \% \mathrm{~B} 1 \mathrm{~m} / \mathrm{a}-2521299$

DW. (2009, Ocak 16). Ortadoğu'da ateşkes umudu. https://www.dw.com/ tr/ortado\%C4\%9Fuda-ate\%C5\%9Fkes-umudu/a-3950987

Ehteshami, A. (2002). The foreign policy of Iran, İçinde Hinnebusch, R.A. \& Ehteshami, A. (Ed.), The foreign policy of Middle East states. (s. 283-309). Lynne Rienner Publishers.

Erik H. E. (1968). Identity: Youth and crisis. W.W. Norton.

Erkan, S. (2010a). İran'a yabancı ülke müdahaleleri (1907-1921). Akademik Ortadoğu Dergisi, 5(1), 92-116.

Erkan, S. (2010b). The invasion of Iran by the allies during World War II. Codrul Cosminului, 16(2), 109-132.

Euro News. (2020, Eylül 15). Iran'dan, BAE ve Bahreyn 'in Ísrail ile normalleşme anlaşması yorumu: Trump'ın sirkinde oynadılar. https:// tr.euronews.com/2020/09/15/

Fars News. (2021, Temmuz 13). Ayetullah Reisi be en-Nehhale ve Haniye: Iran be defağ ez Filistin edame midehed. https://www.farsnews.ir/ news/14000422000964

Firoozadabi, S.J.D. (2011), Ontological security and the foreign policy analysis of the Islamic Republic of Iran. Iran Review of Foreign Affairs, 2(2), 31-60. 
Giddens, A. (1991). The Consequences of Modernity. Polity Press.

Giddens, A. (2019). Modernite ve bireysel-kimlik (3. bs.). (Çev. Ü. Tatl1can). Say Yayınları. (Orijinal yayın tarihi 1993)

Gustafsson, K. (2013). Memory politics and ontological security in SinoJapanese Relations. Asian Studies Review, 38(1), 71-86. https://doi.or $\mathrm{g} / 10.1080 / 10357823.2013 .852156$

Hamanei, A. (2018). İran gerçeği: Konuşmalarından derlemeler. (Çev. İ. Bendiderya). Kaynak Yayınları.

Hansen, F.S. (2016). Russia's Relations with the West: ontological security through conflict. Contemporary Politics, 22(3), 359-375. https:// doi.org/10.1080/13569775.2016.1201314

Hinnebusch, R. (2003). The international politics of the Middle East. Manchester University Press.

Humeyni, R. (t.y.). Velayet-i fakih: İslam devleti. İmam Humeyni'nin Eserlerini Tanzim ve Yayınlama Müessesesi.

Hunter, S. (2010). Iran's foreign policy in the post-Soviet era: Resisting the new international order. Greenwood Publishing.

Huysmans, J. (1998). Security! What do you mean?: From concept to thick signifier. European Journal of International Relations, 4(2), 226-255. https://doi.org/10.1177/1354066198004002004

IRNA. (2016, Aral1k 30). Brucerdi: Filistin'in tek kurtuluş yolu direniştir. https:/tr.irna.ir/news/3394354/

IRNA. (2017, Aralık 27). İslami şura meclisi hükümeti Kudüs'ün tamamını Filistin başkenti olarak desteklemekle görevlendirildi. https:// tr.irna.ir/news/3570845

IRNA. (2017, Aralık 6). Ayetullah Hamenei: Íslam dünyası izzet ve güç istiyorsa birlik ve direnişi kendine düstur etmelidir. https://tr.irna.ir/ news/3547984/

IRNA. (2019, Kasım 15). Ayetullah Hamenei: İslam dünyasının bugünkü musibetlerinin nedeni İslami birliğin zayıflğgldır. https://tr.irna.ir/ news/83556075/ 
IRNA. (2019, Mayıs 31). Kudüs günü ve Iran devrimi. https://tr.irna.ir/ news/83334590/

IRNA. (2019, Mayis 31). SNSC: Iran to continue support to resistance groups. https:/en.irna.ir/news/83334586/

IRNA. (2020, Şubat 5). Islam inkılabı rehberi: Yüzyılın anlaşması, Trump'ın ölmesinden önce ölecektir. https://tr.irna.ir/news/83662239

Islamic Parliament of Iran, The Constitution of the Islamic Republic of Iran, 1989. https://en.parliran.ir/eng/en/Constitution

ISNA. (2020, Şubat 5). American plot of 'deal of the century' will die before Trump dies: Supreme Leader. https://en.isna.ir/ news/98111612043/

Keddie, N. R. (1988). Iranian revolutions in comparative perspective. İçinde E. Burke \& I. M. Lapidus (Ed.). Islam, politics and social movements. (s. 298-313). University of California Press.

Kessler, G. ( 2011, Ekim 5). Did Ahmadinejad really say Israel should be 'wiped off the map'?. Washington Post. https://wapo.st/3DrCC6t

Khamenei.ir. (2019, Ekim 1). The full text of Khamenei.ir's interview with Sayyid Hassan Nasrallah. https://english.khamenei.ir/news/7075/The-full-text-of-Khamenei-ir-s-interview-with-Sayyid-Hassan-Nasrallah

Kinnvall C. \& Mitzen, J. (2017). An introduction to the special issue: Ontological securities in world politics. Cooperation and Conflict, 52(1), 3-11. https://doi.org/10.1177/0010836716653162

Küpeli, M. Ş. (2016). Dış politika aracı olarak yaptırımlar: İran'a uygulanan yaptırımların etkileri. Türkiye Ortadoğu Çalışmaları Dergisi, 3(1), 97-135. https://dergipark.org.tr/tr/pub/tocd/issue/24014/251558

Laing, R. D. (2015). Bölünmüş benlik: Akıl sağlığl ve delilik üzerine varoluşsal bir çalışma (2.bs.). (Çev. E. Akça). Pinhan Yayıncılık. (Orijinal yayın tarihi 1990)

Maloney, S. (2002). Identity and change in Iran's foreign policy. İçinde Telhami, S. \& Barnett, M. (Ed.). Identity and foreign policy in the Middle East. (s. 88-117). Cornell University Press.

Mehr Haber Ajans1. (2008, Eylül 13). Iran nihai zafere kadar Filistin halkl yanında olacaktır. https://tr.mehrnews.com/news/748514/ 
Mehr Haber Ajans1. (2008, Eylü1 25). Ahmedinejad Larry King'e konuk oldu. https://tr.mehrnews.com/news/755231/

Mehr Haber Ajans1. (2010, Aralık 14). Siyonist rejim, Ortadoğu'ya sulta kurma amact ile oluşturuldu. https://tr.mehrnews.com/news/1210429/

Mehr Haber Ajans1. (2012, Nisan 28). Laricani: Kudüs işgalcisi rejim, hali hazırda inzivadadır. https://tr.mehrnews.com/news/1587280/

Menashri, D. (2007). Iran's regional policy: Between radicalism and pragmatism. Journal of International Affairs, 60(2), 153-167. https:// www.jstor.org/stable/24357976

Mepa News. (2020, Ocak 11). Hamas liderinin dilinden: Geçmişten bugüne Hamas-Iran ilişsileri. https://www.mepanews.com/hamas-liderinin-dilinden-gecmisten-bugune-hamas-iran-iliskileri-32825h.htm

Mepa News. (2021, Mayıs 21). Hamas lideri Heniye'den Iran'a 'Gazze' teşsekkürü. https://www.mepanews.com/hamas-lideri-heniyeden-iranagazze-tesekkuru-44518h.htm

Mitzen, J. (2006a). Anchoring Europe's civilizing identity: Habits, capabilities and ontological security. Journal of European Public Policy, 13(2), 270-285. https://doi.org/10.1080=13501760500451709

Mitzen, J. (2006b). Ontological security in world politics: State identity and the security dilemma. European Journal of International Relations, 12(3), 341-370. https://doi.org/10.1177/1354066106067346

Mitzen, J. \& Larson, K. (2017). Ontological security and foreign policy. Oxford Research Encyclopedia of Politics. https:/doi.org/10.1093/ acrefore/9780190228637.013.458

Pars Today. (2017, Kasım 4). İran'da 4 Kasım günü etkinlikleri düzenlendi. https://parstoday.com/tr/news/iran-188669

Pars Today. (2021, Ocak 22). Islam Inknlabı rehberi: pek uzak olmayan bir gelecekte Filistin milleti muzaffer olacak. https://parstoday.com/tr/ news/iran-i123270

Ramazani, R.K. (1992). Iran's foreign policy: Both north and south. Middle East Journal, 46(3), 393-412.

Ruda, B. (2018, Ocak 8). Iranian protests show Iran needn't be more Palestinian than the Palestinians themselves. Jewish Press. https://www. jewishpress.com/indepth/opinions/357573/2018/01/08/ 
Rumelili, B. (2015a). Identity and desecuritisation: The pitfalls of conflating ontological and physical security. Journal of International Relations and Development, 18(1), 52-74. https://doi.org/10.1057/ jird.2013.22

Rumelili, B. (Ed.). (2015b). Conflict resolution and ontological security: peace anxieties. Routledge. https://doi.org/10.4324/9781315796314

Rumelili, B. \& Adısönmez, U. C. (2020). Uluslararası ilişkilerde kimlikgüvenlik ilişkisine dair yeni bir paradigma: ontolojik güvenlik teorisi. Uluslararası İlişkiler, Çevrimiçi Erken Yayın, 1-17. https://doi. org/10.33458/uidergisi.720630

Saad-Ghorayeb, A. (2013, Ağustos 5). İran'ın Filistin davasına adanmışl1ğının ideolojik, siyasi ve stratejik nedenleri üzerine, 5. ABNA. https:// tr.abna24.com/service/middle-east/archive/2013/08/05/448895/story. html

Sadjadpour K. \& Takeyh, R. (2005, Aralık 23). Iran's hard line on Israel. The New York Times. https://nyti.ms/3ywEaIC

Saideman, S. (2002). Thinking theoretically about identity and foreign policy. İçinde S. Telhami \& M. Barnett (Ed.). Identity and foreign policy in the Middle East (s. 169-201). Cornell University Press.

Satloff, R. (2002, May1s 1). The peace process at the sea. Washington Institute. https://www.washingtoninstitute.org/policy-analysis/peaceprocess-sea-karine-affair-and-war-terrorism

Sinkaya, B. (2014). Filistin meselesi, direniş ekseni ve İran. Ortadoğu Analiz, 6(64), 28-31.

Slavin, B. (2007). Bitter friends, bosom enemies: Iran, the U.S., and the twisted path to confrontation. St. Martin's Press.

Steele, B. J. (2008). Ontological security in international relations: Self-identity and the IR state. Routledge. https://doi. org/10.4324/9780203018200

Şen, G. (2016). Devrimden günümüze Iran'ın ABD politikası: Tarihsel sosyolojik bir analiz. ODTÜ Yayınc1lık.

Taghipour, M. T. (1992). Negereşiy ber endişeha-yi hezret-i emam Khomeyni/ sulh ba eşgalgeran vagehgera-yi ya intihar?. Ensani-ir. http:// ensani.ir/fa/article/53480 
Taheri, A. (2008). The Persian Night: Iran under the Khomeinist revolution. Encounter Books.

Tasnim Haber Ajans1. (2017, Haziran 23). Dünya Kudüs günü nedir ve nasıl ortaya çıktı. https://www.tasnimnews.com/tr/ news/2017/06/23/1443925/

Tasnim Haber Ajans1. (2018, Haziran 4). Veladetinden rlhletine imam Humeyni (r.a). https://www.tasnimnews.com/tr/ news/2018/06/04/1742253/

The Iranian News. (1997, Aralık 9). Khatami's speech at Tehran summit. https://iranian.com/News/Dec97/khatami.html?site=archive

The New York Times. (2005, Aralık 15). Iran's president clarifies stand on holocaust: It's a European myth. https://www.nytimes. com/2005/12/15/

The New York Times. (2018, May1s 8). Read the full transcript of Trump's speech on the Iran nuclear deal. https://nyti.ms/3Dthrky

The White House. (2002, Ocak 29). President delivers state of the union address. https://georgewbush-whitehouse.archives.gov/news/releases/2002/01/20020129-11.html

U.S. Department of State, Bureau of Counterterrorism. (2019). Country reports on terrorism 2019. https://www.state.gov/reports/countryreports-on-terrorism-2019/

U.S. Department Of The Treasure. (2018, Kasim 5). U.S. government fully re-imposes sanctions on the Iranian regime as part of unprecedented U.S. economic pressure campaign. https://home.treasury.gov/ news/press-releases/sm541

Weldes, J. (1996). Constructing national interest. European Journal of International Relations, 2(3), 275-318. https://doi. org/10.1177/1354066196002003001

Wendt, A. (1992). Anarchy is what states make of it: The construction of power politics. International Organization, 46(2), 391-425.

Wendt, A. (2012) Uluslararast siyasetin sosyal teorisi. (1.bs). (Çev. H. Sarı Ertem ve S. G. Ihlamur Öner). Küre Yayınları. (Orijinal yayın tarihi 2001) 
Zarakol, A. (2010). Ontological (in)security and state denial of historical crimes: Turkey and Japan. International Relations, 24(1), 3-23. https://doi.org/10.1177/0047117809359040 